\title{
INDEX OF AUTHORS
}

Adeleye, G. I.

Armstrong, J. A.

Baecke, J. A. H.

Bassett, J. M.

Beames, R. M.

Beever, D. E.

Bender, D. A.

Blourde, $\mathrm{C}$.

Bueno, L.

Burema, J.

Chwalibog, A.

Coates, M. E.

Corring, $\mathrm{T}$.

Deurenberg, P.

Eggum, B. O.

Evans, J.

Field, A. C.

Ford, E. J. H.

Frape, D. L.
Gill, M.

Gregg, V. A.

Hegde, S. N.

Hodgson, J. C.

Johnson, A. O. K.

Jones, E.

Keal, H. D.

Low, A. G.

Magboul, B. I.

Mellor, D. J.

1 Milligan, L. P. Morgan, B. L. G.

161

111

Naismith, D. J.

Newport, M. J.

49

111

97

Osunkoya, B. O.
Henckel, S.

\begin{tabular}{r|lr}
37 & Partridge, I. G. & 137 \\
65 & & 177 \\
73 & Randall, C. J. & 129 \\
161 & Roche, M. & 73 \\
49 & Rolls, B. A. & \\
& Salimonu, L. S. & 7 \\
7 & Sambrook, I. E. & 137 \\
97 & Samson, D. E. & 59 \\
& Slee, J. & 59 \\
89 & Syme, G. & 25 \\
& & 59 \\
137,147 & Thompson, G. E. & 161 \\
& Thorbek, G. & 97 \\
119 & Tuck, M. G. & 129 \\
49 & & \\
65 & Vagne, M. & 81 \\
15 & Waddington, D. & 97 \\
& Wayman, B. J. & 177 \\
89 & Whitehead, C. C. & 119 \\
7 & Williams, A. I. O. & Wynick, D.
\end{tabular}

177

29$$
7
$$$$
37
$$ 


\section{The British Journal of Nutrition}

\section{Volume 48 No. 1 July 1982}

\section{CONTENTS}

\section{Papers of direct reference to CLINICAL AND HUMAN NUTRITION}

Baecke Jos A. H., Burema Jan \& Deurenberg Paul. Body fatness, relative weight and frame size in young adults

Salimonu L. S., Johnson A. O. K., Williams A. I. O., Adeleye G. Iyabo \& Osunkoya B. O. Lymphocyte subpopulations and antibody levels in immunized malnourished children

Papers on GENERAL NUTRITION

Morgan B. L. G. \& Naismith D. J. The effect of early postnatal undernutrition on the growth and development of the rat brain

Syme Gabrielle. The effect of protein-deficient isoenergetic diets on the growth of rat jejunal mucosa

Gill Margaret \& Beever D. E. The effect of protein supplementation on digestion and glucose metabolism in young cattle fed on silage

Hodgson J. C., Mellor D. J. \& Field A. C. Foetal and maternal rates of urea production and disposal in well-nourished and undernourished sheep

Thompson G. E., Bassetr J. M., Samson Debbie E. \& Slee J. The effects of cold exposure of pregnant sheep on foetal plasma nutrients, hormones and birth weight

GregG V. A. \& Milligan L. P. In vitro energy costs of $\mathrm{Na}^{+}, \mathrm{K}^{+}$-ATPase activity and protein synthesis in muscle from calves differing in age and breed

Hegde S. N., Rolls B. A. \& Coates Marie E. The effects of the gut microflora and dietary fibre on energy utilization by the chick

Whitehead C. C., Armstrong J. A. \& Waddington D. The determination of the availability to chicks of biotin in feed ingredients by a bioassay based on the response of blood pyruvate carboxylase (EC 6.4.1.1) activity

Newport M. J. \& Keal H. D. Artificial rearing of pigs. 12. Effect of replacement of dried skimmilk by either a soya-protein isolate or concentrate on the performance of the pigs and digestion of protein

Frape D. L., Wayman B. J., Tuck Mary G. \& Jones E. The effects of gum arabic, wheat offal and various of its fractions on the metabolism of ${ }^{14} \mathrm{C}$-labelled aflatoxin $\mathrm{B}_{1}$ in the male weanling rat

Ford E. J. H. \& Evans JoAN. Glucose utilization in the horse

Bender David A., Magboul Bahieldin I. \& Wynick David. Probable mechanisms of regulation of the utilization of dietary tryptophan, nicotinamide and nicotinic acid as precursors of nicotinamide nucleotides in the rat

Roche Maurice, Bueno Lionel, Vagne Monique \& Blourde Christian. Patterns of electrical activity in the digestive tract of the conscious cat

Partridge I. G., Low A. G., SAmbrook I. E. \& Corring T. The influence of diet on the exocrine pancreatic secretion of growing pigs

Low A. G. The activity of pepsin, chymotrypsin and trypsin during $24 \mathrm{~h}$ periods in the small intestine of growing pigs

Eggum B. O., Thorbek Grete., Beames R. M., Chwalibog A. \& Henckel S. Influence of diet and microbial activity in the digestive tract on digestibility, and nitrogen and energy metabolism in rats and pigs

WhitehEAd C. C. \& RANDALl C. J. Interrelationships between biotin, choline and other B-vitamins and the occurrence of fatty liver and kidney syndrome and sudden death syndrome in broiler chickens

C) The Nutrition Society 1982

For Index of Authors see inside back cover

CAMBRIDGE UNIVERSITY PRESS

The Pitt Building, Trumpington Street, Cambridge CB2 1RP

32 East 57th Street, New York, N.Y. 10022

Printed in Great Britain at the University Press, Cambridge 